\title{
DAMPAK LETUSAN GUNUNG KRAKATAU 1883 TERHADAP PERMUKIMAN DI PANTAI BARAT TELUK LAMPUNG
}

\author{
The Impact of the 1883 Krakatau Eruption on the Settlement on West Beach of \\ Lampung Gulf
}

\author{
Nanang Saptono \\ Balai Arkeologi Jawa Barat \\ Jalan Raya Cinunuk Km. 17 Cileunyi, Bandung \\ E-mail: nanangsaptono@gmail.com
}

\begin{abstract}
Volcanic eruptions often have a negative impact on surrounding settlements. The condition of the object at the Liyangan site in Temanggung Regency is one proof of the negative impact of the volcanic eruption. Several archaeological studies of the sites around Mount Merapi, Yogyakarta concluded that the eruption of Mount Merapi was one of the reasons for the migration of ancient Mataram civilization from central of Java to eastern of Java. The eruption of Mount Krakatau in the Sunda Strait in 1883 also caused disasters to the surrounding community. The story of the people of Lampung explains that the eruption of Mount Krakatau has obliterated the village so that the community moved the village. On the west coast of Lampung Bay, there are several settlement sites, namely Kampung Tuha Maja Saka, Benteng Belajung, and Kahai. This study discusses the impact of the 1883 eruption of Mount Krakatau on these villages. The research method is descriptive and supported by laboratory analysis of the traces of the eruption material. Eruption traces were found at several object locations. The move of Kampung Tuha Maja Saka to a new location was not the result of the 1883 Krakatau eruption.
\end{abstract}

Keywords: Mount Krakatau; eruption; tsunami; settlement

\begin{abstract}
Abstrak
Letusan gunung berapi seringkali memberikan dampak negatif terhadap permukiman di sekitarnya. Kondisi objek seperti pada situs Liyangan di Kabupaten Temanggung merupakan salah satu bukti dampak negatif letusan gunung. Beberapa kajian arkeologi terhadap situs-situs di sekitar Gunung Merapi, Yogyakarta menyimpulkan bahwa erupsi Gunung Merapi menjadi salah satu alasan pindahnya peradaban Mataram Kuno dari Jawa Tengah ke Jawa Timur. Letusan Gunung Krakatau di Selat Sunda pada tahun 1883 juga menimbulkan bencana terhadap masyarakat di sekitarnya. Cerita masyarakat Lampung menjelaskan bahwa erupsi Gunung Krakatau telah melenyapkan perkampungan sehingga masyarakat memindahkan perkampungannya. Di pantai barat Teluk Lampung terdapat beberapa situs permukiman yaitu Kampung Tuha Maja Saka, Benteng Belajung, dan Kahai. Kajian ini membahas dampak letusan Gunung Krakatau 1883 terhadap perkampungan-perkampungan tersebut. Metode penelitian melalui deskripsi dan didukung analisis laboratoris terhadap jejak material erupsi. Jejak erupsi ditemukan pada beberapa lokasi objek. Perpindahan Kampung Tuha Maja Saka ke lokasi baru bukan merupakan akibat dari letusan Krakatau 1883.
\end{abstract}

Kata kunci: Gunung Krakatau; erupsi; tsunami; pemukiman 


\section{PENDAHULUAN}

Wilayah Indonesia banyak terdapat gunungapi baik yang masih aktif maupun yang sudah mati. Meskipun aktivitas gunungapi seringkali memberikan dampak negatif namun secara budaya gunungapi dipandang dekat dengan kelangsungan hidup manusia. Gunungapi merupakan sumber kekuatan, tempat bersemayamnya arwah leluhur, dan tempat para dewa. Tercatat banyak sekali situs-situs permukiman berada di lereng gunungapi. Ibukota Kerajaan Mataram Kuno di lereng Gunung Merapi menyisakan banyak tinggalan berupa bangunan-bangunan candi. Selain Gunung Merapi, di Jawa Tengah terdapat Gunung Sindoro yang dahulu pernah sebagai gunungapi aktif.

Aktivitas vulkanik Gunung Sindoro telah menimbun permukiman kuno Liangan. Liangan merupakan situs masa Mataram Kuno abad ke-9 - ke-10 Masehi yang memiliki komponen permukiman berupa area hunian, area peribadatan Hindu sebagimana ditunjukkan oleh temuan yoni dan lingga, area pertanian, dan area perbengkelan. Area hunian ditandai dengan ditemukannya sisa rumah kayu, peralatan rumah tangga dari keramik, tembikar, logam, dan batu. Area peribadatan Hindu ditandai oleh bangunan candi Hindu, bangunan batur, dan peralatan peribadatan berupa genta perunggu dan arca. Area pertanian ditandai oleh sebaran yoni di bagian atas situs, peralatan pertanian dari logam, dan sisa padi yang hangus terbakar oleh materi vulkanik. Data arkeologi di situs Liangan yang meliputi unsur-unsur permukiman memang sangat beragam yang secara integral sekaligus mencerminkan peradaban di Liangan kuno (Riyanto, 2015).

Selain di Liangan, jejak pemukiman kuno yang tertimbun material vulkanik juga dapat dijumpai di situs Tambora. Pada April 1815 Gunung Tambora meletus. Letusan Tambora telah mengisi \pm 60 mega ton sulfur ke lapisan stratosfer, enam kali lipat lebih banyak dari sulfur yang terlontar dalam letusan Gunung Pinatubo tahun 1991. Pengamatan yang dilakukan Haraldur Sigursson, tahun 2006. Pada Tahap awal terdapat dua endapan letusan tipe plinian berupa abu dan batu apung abu-abu, membentuk perlapisan endapan setebal 40-150 cm menutupi hampir seluruh lereng dan juga tersebar ke bagian barat di luar wilayah gunungapi. Letusan puncak terjadi pada pukul 19.00 WITA, 11 April di mana gerakan piroklastik sangat dahsyat mengalir hampir ke segala arah, terutama ke arah utara, barat, dan selatan dari pusat letusan. Atas dasar jejak letusan yang diamati diketahui ada dua episode pertama terdiri dari empat tahap selang seling antara jatuhnya abu tephra, dan aliran piroklastik. Letusan menghasilkan kolom setinggi 33-43 terjadi di antara dua letusan abu dan batu apung (plinian) yang dikenal sebagai letusan bersejarah. Perubahan tiba-tiba setelah aliran piroklastik plinian kedua terjadi pada tanggal 10 adalah meningkatnya letusan hebat meruntuhkan puncaknya membentuk lubang kaldera, pelebaran lubang, bagian dari ventilasi baru. Sedikitnya ada delapan aliran piroklastik dan gelombang panas. Gelombang yang datang pertama telah menyapu Desa Tambora, luluh lantakan bangunan, desa, dan tewaskan begitu banyak orang (Wibisono, 2017). Letusan dahsyat Gunung Tambora telah mengubur Dusun Oibura, Kecamatan Tambora. 
Penelitian di situs Tambora, Dusun Oibura telah banyak menemukan sisa-sisa kehidupan masyarakat yang bermukim di lereng Gunung Tambora pada waktu letusan. Temuan tersebut antara lain berupa komponen bangunan, gerabah, keramik, tali tambang, anyaman atap ijuk, batu pipisan, buah kemiri, bulir padi, keris, rangka manusia dan lain-lain. Situs Tambora adalah bagian dari kawasan Gunung Tambora yang pada awalnya berdiri tiga buah kerajaan yaitu Kerajaan Tambora, Kerajaan Pekat dan Kerajaan Sanggar (Haribuana, 2013).

Tidak begitu lama setelah letusan Gunung Tambora, pada 1883 Gunung Krakatau di Selat Sunda meletus. Kawasan terdekat yang terkena dampak langsung adalah daerah Banten dan Lampung bagian selatan. Rakyat Banten pada 1879 mendapat bencana wabah penyakit ternak. Selanjutnya disusul wabah demam yang menyebabkan lebih dari $10 \%$ penduduk meninggal. Belum lagi suasana membaik, pada 1883 Gunung Krakatau meletus. Letusan itu sangat dahsyat. Lebih dari 20.000 orang jadi korban meninggal. Banyak desa yang makmur menjadi hancur. Sawah subur menjadi gersang. Di daerah Caringin dan Anyer luas lahan yang tidak dapat digarap menjadi semakin luas (Kartodirdjo, 2015; Tantri, 2014). Di Banten dampak letusan hingga di kampung nelayan Karang Hantu. Banyak warga yang terseret gelombang tsunami (Zarman, 2013). Di daerah ujung selatan Lampung banyak desa-desa yang hancur akibat tsunami dan letusan Gunung Krakatau. Desa-desa seperti Bumi, Ketimbang, Talang, Kupang, Lampasing, Umbul Batu, Benawang, Badak, Limau, Lutung, Gunung Basa, Gunung Sari, Minanga, Tanjung, Kampung Teba, Kampung Menengah, Kuala, Rajabasa, Tanjung Karang, juga Pulau Sebesi, Pulau Sebuku, dan Pulau Merak hancur parah (Suryadi, 2009).

Peristiwa meletusnya Gunung Krakatau pada 1883 meninggalkan ingatan kuat pada kalangan masyarakat. Ingatan kolektif masyarakat inilah seringkali dikaitkan dengan berbagai akibat. Beberapa peristiwa budaya dikatakan sebagai akibat dari letusan Gunung Krakatau. Di Lampung Selatan terdapat situs-situs pemukiman yang merupakan bekas kampung tua. Tradisi masyarakat menyebutkan bahwa kampungkampung tua tersebut ditinggalkan karena letusan Gunung Krakatau 1883. Situs-situs kampung tua tersebut adalah situs Pekon Tuha Maja Saka, Benteng Belajung, dan Kampung Kahai. Berdasarkan tradisi lisan yang berkembang di masyarakat, terdapat permasalahan yang perlu diungkap yaitu bagaimanakah dampak letusan Krakatau terhadap kampung-kampung tua tersebut, apakah terdapat kesesuaian antara tradisi lisan dengan kondisi yang sebenarnya berdasarkan jejak tinggalan yang ditemukan di beberapa lokasi situs-situs permukiman. Untuk menjawab permasalahan ini akan diterapkan metode penelitian deskriptif. Pengumpulan data dilalukan melalui observasi langsung pada beberapa situs permukiman. Berdasarkan data yang terkumpul kemudian dilakukan interpretasi terhadap fakta di lapangan dan keterangan cerita masyarakat. Khusus untuk situs Pekon Tuha Maja Saka pengumpulan data juga dilakukan melalui ekskavasi. Material vulkanik yang ditemukan melalui ekskavasi kemudian dilakukan analisis XRF untuk mengetahui kandungan unsur. Melalui perbandingan kandungan unsur tersebut akan dibahas mengenai erupsi yang pernah terjadi. 


\section{HASIL DAN PEMBAHASAN}

\section{Kampung-kampung Tua di Pantai Barat Teluk Lampung}

Di Lampung Selatan, khususnya sekitar Gunung Rajabasa pada masa awal terbentuknya Keratuan Darah Putih terdapat beberapa kampung yang kemudian bersatu bergabung dalam Keratuan Darah Putih. Kampung-kampung tua tersebut antara lain Kampung Tuha Maja Saka, Belajung, dan Kahai (gambar 1). Ketiga kampung ini sekarang sudah pindah ke lokasi baru di tepi jalan raya. Dalam tradisi lisan masyarakat, perpindahan kampung dikarenakan letusan Gunung Krakatau.

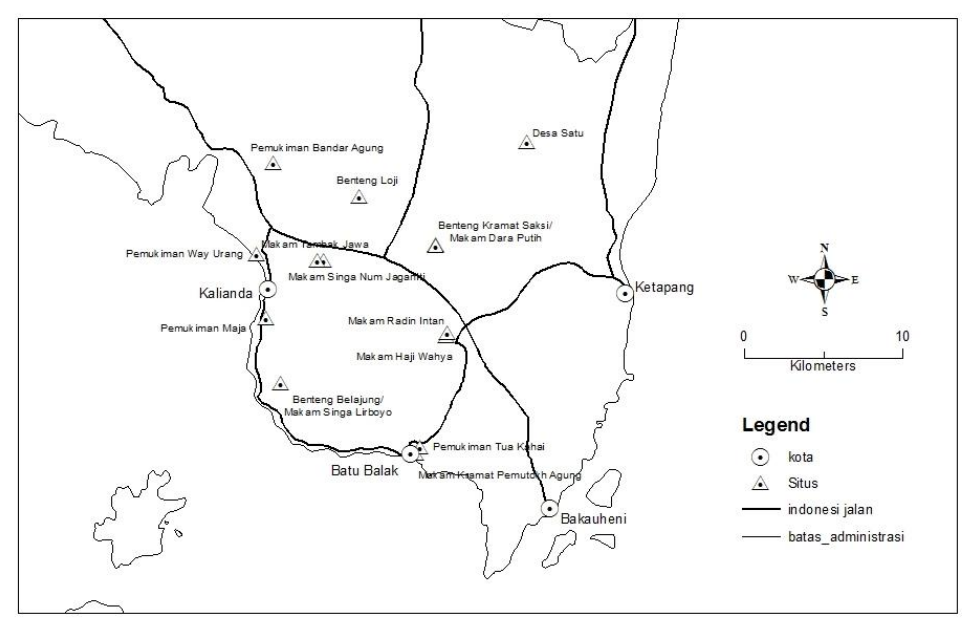

Peta Situs Pemukiman Kabupaten Lampung Selatan, Propinsi Lampung.

Gambar 1. Situs permukiman di pantai barat Teluk Lampung (Sumber: Dokumen Balai Arkeologi Jawa Barat, 2015).

1. Situs Pekon Tuha Maja Saka

Situs Pekon Tuha Maja Saka merupakan pemukiman Desa Maja sebelum pindah. Lokasi itu secara administratif termasuk di wilayah Desa Maja, Kecamatan, Kalianda. Lokasi situs berada pada satuan geomorfologi dataran bergelombang lereng barat laut Gunung Rajabasa. Secara geografis berada pada posisi $5^{\circ} 45^{\prime} 33.31^{\prime \prime}$ LS dan 105³5'18.52" BT dengan ketinggian $37 \mathrm{~m}$ dpl.

Batas situs bagian utara dan timur tidak begitu jelas, batas selatan dan barat adalah aliran Way Maja (gambar 2). Sungai ini mengalir dari timur ke barat kemudian ke arah utara dan bermuara di Teluk Lampung. Lahan situs dimanfaatkan untuk kebun kakao (Theobroma cacao) diselingi dengan tanaman keras seperti misalnya petai (Parkia speciosa) nangka dan mangga (Mangifera indica). Topografi lahan situs relatif tidak rata, miring ke arah selatan dan barat. Pada sisi selatan terdapat bagian landai mengarah ke sungai. Beberapa kumpulan batu membentuk gundukan terdapat di lahan situs secara sporadis. Sebaran pecahan keramik dan tembikar juga dijumpai secara sporadis dengan konsentrasi relatif tinggi terdapat di sisi bagian tengah dan sisi selatan (Saptono \& Widyastuti, 2015; Saptono, Widyastuti, \& Hidayat, 2017). 


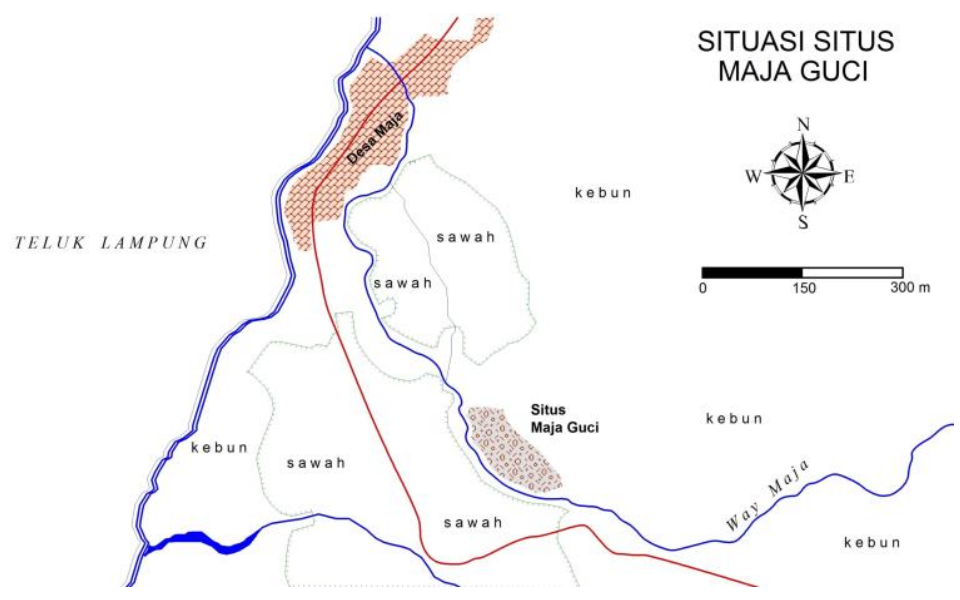

Gambar 2. Situasi situs Pekon Tuha Maja Saka, Desa Maja, Kecamatan Kalianda (Sumber: Dokumen Balai Arkeologi Jawa Barat, 2017).

\section{Benteng Belajung}

Latar sejarah pemukiman Benteng Belajung berupa tradisi lisan yang menjadi ingatan kolektif masyarakat Kahai. Menurut tradisi lisan masyarakat yang disampaikan oleh Juheruddin gelar Dalom Kesuma Ratu (68 th), pembentukan pemukiman di Benteng Belajung terjadi pada sekitar tahun 1550 oleh pendatang dari Surabaya bernama Harun. Di Lampung kemudian berbaur dengan masyarakat dan diakui sebagai orang Lampung. Pemukiman di Belajung dikembangkan oleh Raden Mas yang merupakan generasi ketiga dari Harun. Raden Mas dikenal sebagai tokoh yang bersamasama Raden Intan I berjuang melawan kolonial. Pada masa perlawanan Pangeran Singa Brata (1850-1856) Benteng Belajung merupakan tempat untuk menyembunyikan kaum ibu dan anak-anak dan juga sebagai gudang logistik (Hadikusuma, 1989). Puncak perkembangan pemukiman Benteng Belajung berlangsung pada masa Dalom Kesuma Ratu (generasi ke lima). Pada masa ini jalinan perdagangan di Belajung hingga ke Singapura. Pada masa selanjutnya pemukiman pindah ke Canti hingga sekarang (Saptono \& Widyastuti, 2015).

Benteng Belajung juga disebut Benteng Pala atau Benteng Hawi Beghak. Secara administratif berada di wilayah Desa Canti, Kecamatan Rajabasa (gambar 3). Geomorfologi kawasan berupa dataran bergelombang lereng barat daya Gunung Rajabasa. Secara geografis berada pada posisi $5^{\circ} 47^{\prime} 46.79^{\prime \prime}$ LS dan $105^{\circ} 35^{\prime} 48.34^{\prime \prime}$ BT dengan ketinggian $115 \mathrm{~m}$ dpl. Topografi lahan situs miring ke arah barat. Lokasi benteng berada di antara dua aliran sungai kecil. Di sebelah utara, mengalir dari arah timur ke barat terdapat Way Lappay, sedangkan di selatan situs terdapat aliran Way Belajung. Kondisi lahan pada saat ini berupa kebun tanaman keras. Salah satu tanaman yang dibudidayakan adalah pala (Myristica fragrans Houtt).

Struktur benteng terbuat dari susunan batu. Kondisi yang terlihat sekarang, tinggi struktur batu bervariasi antara $50-70 \mathrm{~cm}$ dan lebar sekitar $50 \mathrm{~cm}$. Denah benteng berbentuk segi empat tidak beraturan. Sisi utara panjangnya $238 \mathrm{~m}$, panjang sisi timur $59 \mathrm{~m}$, sisi selatan $215 \mathrm{~m}$, dan sisi barat $112 \mathrm{~m}$. Pada sisi barat bagian utara terdapat jalan 
menuju makam Singa Lirbaya, anak Harun. Di belakang benteng (sebelah timur) terdapat parit yang ujung utaranya berada di Way Lappay dan ujung selatan di Way Belajung. Di sebelah barat dan selatan benteng terdapat jalan kampung. Jalan kampung di sebelah selatan benteng ada yang memotong bagian benteng, karena di bagian barat posisi jalan berada di sebelah selatan kemudian pada pertengahan sisi selatan jalan tersebut sedikit berbelok dan posisinya kemudian berada di sebelah utara benteng.

Makam Singa Lirbaya berada di sisi utara lahan benteng. Kondisi makam sudah dilengkapi jirat dan cungkup yang merupakan bangunan baru. Pada bagian tengah lahan benteng terdapat beberapa kumpulan batu yang membentuk formasi segi empat menyerupai umpak bangunan kayu. Observasi pada permukaan dijumpai sebaran fragmen keramik dan tembikar.

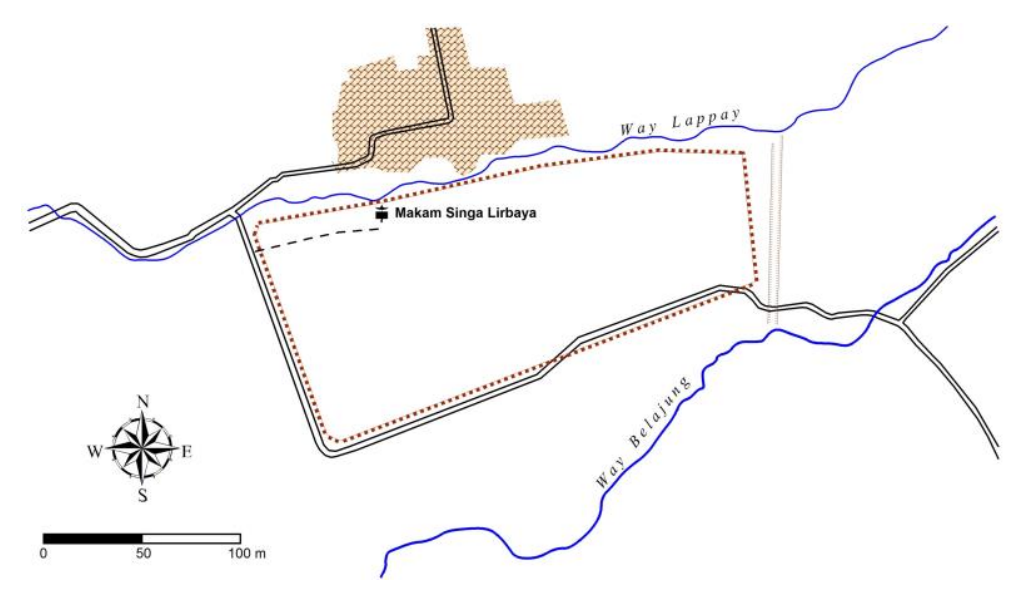

Gambar 3. Situasi Benteng Belajung, Desa Canti, Kecamatan Rajabasa (Sumber: Dokumen Balai Arkeologi Jawa Barat, 2015).

\section{Kampung Kahai}

Situs Kampung Kahai lama berada di tepi pantai selatan Teluk Lampung (Saptono \& Widyastuti, 2015). Geomorfologi kawasan Kahai berupa dataran bergelombang pada lereng selatan Gunung Rajabasa. Latar belakang sejarah Kampung Kahai berhubungan dengan tokoh Pemutokh Agung. Situs Kampung Kahai secara administratif termasuk di wilayah Desa Batu Balak, Kecamatan Rajabasa. Lokasi situs berada pada posisi geografis 550'1.76" LS dan 10540'32.92" BT dengan ketinggian 29 $\mathrm{m}$ dpl. Topografis lahan situs miring ke arah selatan.

Kondisi lahan situs berupa kebun kakao (Theobroma cacao). Di sebelah timur lahan situs terdapat aliran sungai kecil. Mata air sungai ini keluar dari tebing batu yang berada di sebelah utara lahan situs. Masyarakat menamakan mata air tersebut pancur emas. Di sebelah utara lahan situs terdapat parit kecil yang airnya dari pancur emas. Parit tersebut mengalir ke arah barat kemudian belok ke arah selatan bersatu dengan sungai yang berada di sebelah barat lahan situs. Lahan situs terbelah oleh jalan yang sedang dibangun untuk keperluan penambangan batu (gambar 4). Observasi 
dipermukaan banyak terdapat pecahan keramik baik di lahan sebelah utara jalan maupun di sebelah selatan jalan.

Di sebelah barat daya situs berjarak lurus sekitar $315 \mathrm{~m}$ terdapat makam Pemutokh Agung. Lahan makam berada di kawasan pantai pada sisi selatan sungai. Di sebelah selatan makam terdapat lahan untuk tambak udang. Pada lahan kompleks makam Pemutokh Agung terdapat beberapa makam lain. Makam Pemutokh Agung berada di tengah lahan, tepatnya pada posisi geografis 5 50'9.65" LS dan 105²0'26.01" BT dengan ketinggian $5 \mathrm{~m}$ dpl. Makam Pemutokh Agung dilengkapi jirat dan cungkup yang merupakan bangunan baru.

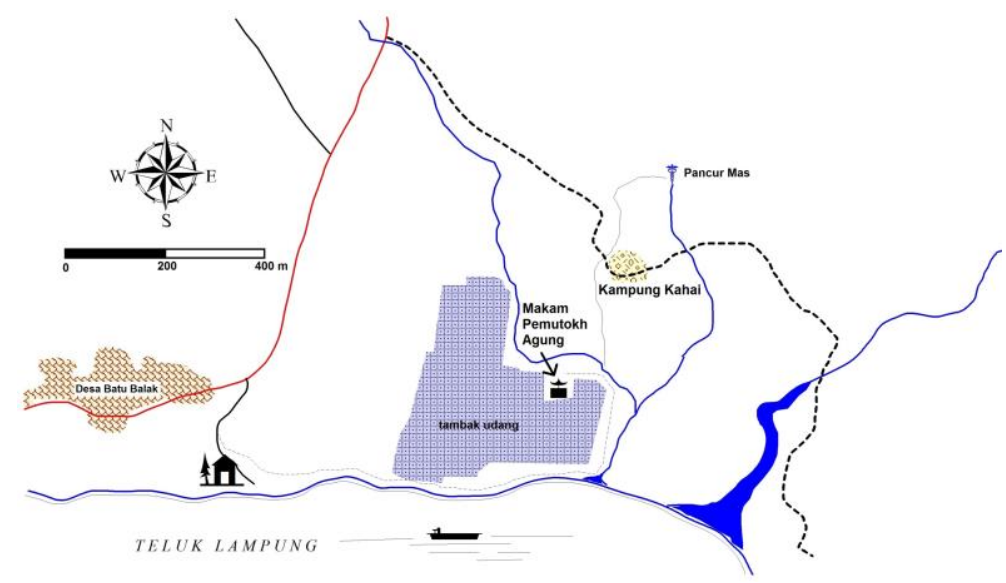

Gambar 4. Keletakan objek arkeologi di Kampung Kahai, Desa Batu Balak, Kecamatan Rajabasa (Sumber: Dokumen Balai Arkeologi Jawa Barat, 2017).

\section{Bencana Dari Gunung Krakatau}

Gunung Krakatau berada di Selat Sunda, dikelilingi Pulau Rakata, Sertung, dan Pulau Panjang atau Sertung Kecil. Secara administratif berada di wilayah Kecamatan Kalianda, Kabupaten Lampung Selatan, Lampung. Pujangga Ronggowarsito di dalam naskah Pustaka Raja Purwa sebagaimana dikutip $\operatorname{Iim}$ Imadudin (2006, 27), mengemukakan letusan besar Gunung Krakatau pernah terjadi pada tahun 416. Di tahun 338 Saka (416 M) suara menggelegar letusan Gunung Kapi terdengar dari Gunung Batuwara. Seluruh negeri hingga bagian timur gunung yang disebut Batuwara hingga Gunung Kamula dan ke barat hingga Gunung Rajabasa dibanjiri air laut. Penduduk bagian utara negeri Sunda hingga Gunung Rajabasa tenggelam dan hanyut beserta semua harta miliknya. Ronggowarsito menyebut Gunung Krakatau dengan Gunung Kapi.

Puncak letusan Gunung Krakatau pada 1883 berlangsung pada 26-28 Agustus 1883. Menurut Risalah Lampung Karam yang selesai ditulis oleh Muhammad Saleh pada hari Senin 14 Zulhijjah $1300 \mathrm{H}$ dan pertama kali diterbitkan pada $1306 \mathrm{H}$ disebutkan bahwa meletusnya Gunung Krakatau terjadi pada 22 Syawal 1300 H (Saleh, 2014). Bencana letusan Gunung Krakatau diceritakan menelan banyak korban. Di 
Umbul Batu dekat Tarahan korban meninggal tidak terhitung bahkan dikatakan tiadalah hidup barang seorang. Penanganan mayat dilakukan dengan dikubur secara masal. Lubang besar digali untuk mengubur 390 mayat. Lubang lain digali untuk mengubur 160 mayat. Mengenai kondisi di sekitar pantai barat Teluk Lampung disebutkan (Saleh, 2014, 59),

Dekat Kitambang namanya lagi

Rajabasa namanya pasti

Orangnya banyak nyata sekali

Limaratus kabar dan peri

Mati sekalian orangnya itu

Tiada yang hidup barang suatu

Sudah diperiksa nyatalah tentu

Api dan batu empunya laku

Bencana yang diakibatkan dari letusan Gunung Krakatau pada 1883 selain hujan abu vulkanik dan material vulkanik lainnya juga gelombang tsunami. Di beberapa lokasi terdampak, tinggi gelombang tsunami tidak sama. Berdasarkan penelitian yang pernah dilakukan, letusan Gunung Krakatau pada 1883 menyebabkan terjadi gelombang tinggi. Beberapa alat pengukur gelombang menunjukkan bahwa tinggi gelombang kurang dari $3 \mathrm{~m}$. Nilai ini dalam kenyataannya jauh lebih kecil dari pada yang teramati. Tinggi gelombang di pantai Sumatera rata-rata $15 \mathrm{~m}$ sedangkan di Jawa sekitar $30 \mathrm{~m}$. Hal ini karena pantai di Sumatera terlindungi beberapa pulau seperti Pulau Rakata (Giachetti, Paris, Kelfoun, \& Ontowirjo, 2012).

Di Sumatera pun tidak semuanya sama. Kawasan pantai barat Teluk Lampung tidak begitu terdampak karena terlindungi Pulau Sebuku dan Sebesi. Fakta ini ditunjukkan oleh orientasi garis pantai yang ada di Provinsi Lampung. Secara garis besar garis pantai yang mendapatkan ekspose serangan gelombang, karena tidak adanya rintangan yang berupa pulau-pulau yang berada di depannya, maka garis pantai tersebut dalam skala waktu yang cukup lama akan mengalami abrasi pantai yang berakibat mundurnya garis pantai. Pada sisi lain, garis-garis pantai yang terlindung oleh pulaupulau di depannya akan menunjukkan kecenderungan untuk maju ataupun stabil dinamis. Teluk Lampung dan Teluk Semangka merupakan kenampakan geologis yang terekspose oleh serangan gelombang yang terjadi dalam waktu lama. Sedangkan fenomena yang ada pada garis pantai yang berada di kaki Gunung Rajabasa merupakan bukti geologis yang menyatakan bahwa garis pantai yang terlindung oleh Pulau Sebesi dan Pulau Sebuku akan menunjukkan gejala majunya garis pantai. Sedangkan daerah sekitar yang terkena oleh serangan gelombang (wind waves, swell, dan tsunami) menunjukkan mundurnya garis pantai sebagai akibat ikutan adanya proses abrasi. Dengan demikian pada daerah yang terekspose tersebut ditemukan batuan-batuan yang terbawa oleh gelombang tsunami dan terdisposisi sampai ke daratan tergantung pada panjang rayapannya (Jokowinarno, 2009).

Situs-situs arkeologi di kawasan pantai barat Teluk Lampung menunjukkan bekas pemukiman. Situs Pekon Tuha Maja Saka mengandung indikator pemukiman 
berupa struktur batu yang diduga merupakan bekas fondasi bangunan (rumah), fitur bekas jalan, dan sebaran pecahan keramik dan tembikar. Di situs Benteng Belajung (Canti) terdapat struktur benteng yang terbuat dari tanah dan batu andesit. Pada area benteng juga ditemukan sebaran artefak keramik dan tembikar yang menunjukkan aktivitas permukiman. Jejak permukiman juga ditemukan di situs Kahai berupa sebaran keramik dan tembikar (Saptono, 2016). Kampung-kampung tua tersebut berada pada pantai yang terlindungi. Apabila tinggi gelombang rata-rata di Lampung yaitu $15 \mathrm{~m}$ maka kampung-kampung itu pun tidak terdampak gelombang tsunami. Diketahui bahwa pemukiman di situs Pekon Tuha Maja Saka adalah $37 \mathrm{~m}$ dpl, situs Benteng Belajung 115 m dpl, dan Kahai berada pada ketinggian 39 m dpl (gambar 5) maka kampungkampung tersebut berada di atas elevasi gelombang tsunami Krakatau.

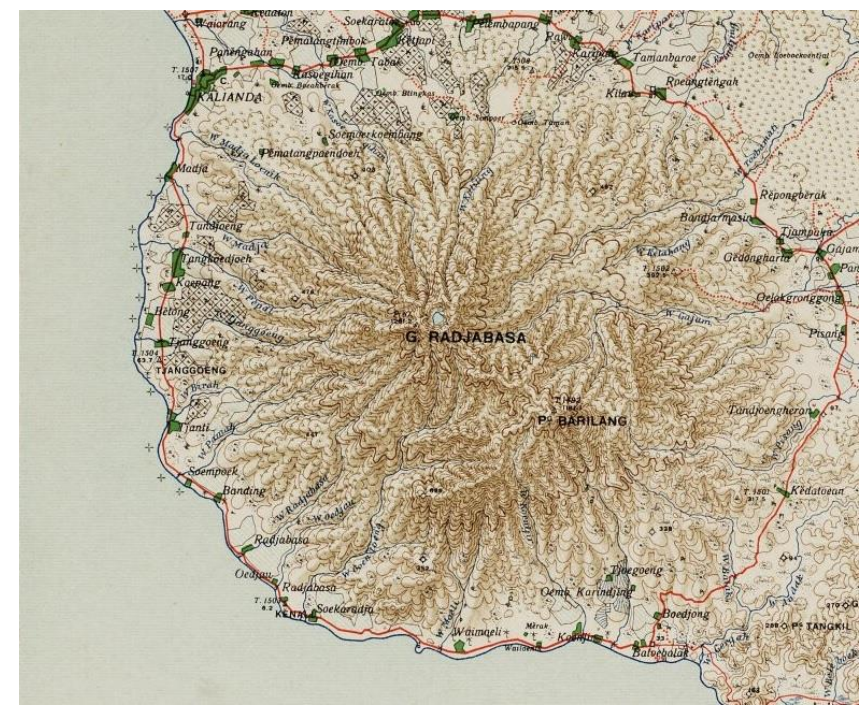

Gambar 5. Peta topografi kawasan pantai barat Teluk Lampung (Sumber: https://ubl.webattach.nl/cgi-bin/iipview?krtid=2440\&marklat=-

5.261631\&marklon=105.225045\&sid=i34kjh6081853\&svid=619984\&lang=1\#focus)

Penelitian dalam bentuk ekskavasi di situs Pekon Tuha Maja Saka, pada kedalaman sekitar $40 \mathrm{~cm}$ ditemukan lapisan tanah berwarna abu-abu dengan ketebalan berkisar 5-10 cm. Kotak ekskavasi tersebut adalah kotak LU 1, LU 6, dan LU 10 (Saptono et al., 2017). Hasil analisis melalui metode XRF menunjukkan pada ketiga sampel didominasi unsur $\mathrm{SiO}_{2}, \mathrm{Al}_{2} \mathrm{O}_{3}$ dan $\mathrm{Fe}_{2} \mathrm{O}_{3}$ (Saptono, 2018). Secara umum material dari letusan gunung berapi mengandung oksida beberapa unsur logam seperti $\mathrm{Si}, \mathrm{Al}, \mathrm{Fe}, \mathrm{Ca}, \mathrm{Mg}, \mathrm{Na}$, dan $\mathrm{K}$ serta belerang dan mungkin beberapa logam berat berbahaya seperti timbal, kadmium, dan arsen (Cas \& Wright, 1988; Christenson, 2000)

Berdasarkan perbadingan unsur pada sampel dengan unsur pada material letusan gunung berapi pada umumnya, menunjukkan bahwa lapisan batuan yang terlihat pada hasil ekskavasi di situs Pekon Tuha Maja Saka merupakan material erupsi gunungapi. Pada beberapa kotak ekskavasi terlihat bahwa artefak ditemukan mulai spit 1 hingga spit terakhir. Sementara lapisan abu vulkanik sebagai jejak letusan gunung dijumpai 
pada spit 2 - 3 (gambar 6). Artefak ditemukan di bawah lapisan abu vulkanik dan di atas abu vulkanik (Saptono et al., 2017). Hal ini menunjukkan bahwa sebelum dan sesudah letusan gunung, Pekon Tuha Maja Saka tetap dihuni. Berdasarkan fakta-fakta tersebut pindahnya pemukiman dari lokasi Pekon Tuha Maja Saka ke lokasi yang baru bukan karena bencana meletusnya Gunung Krakatau melainkan karena alasan lain.
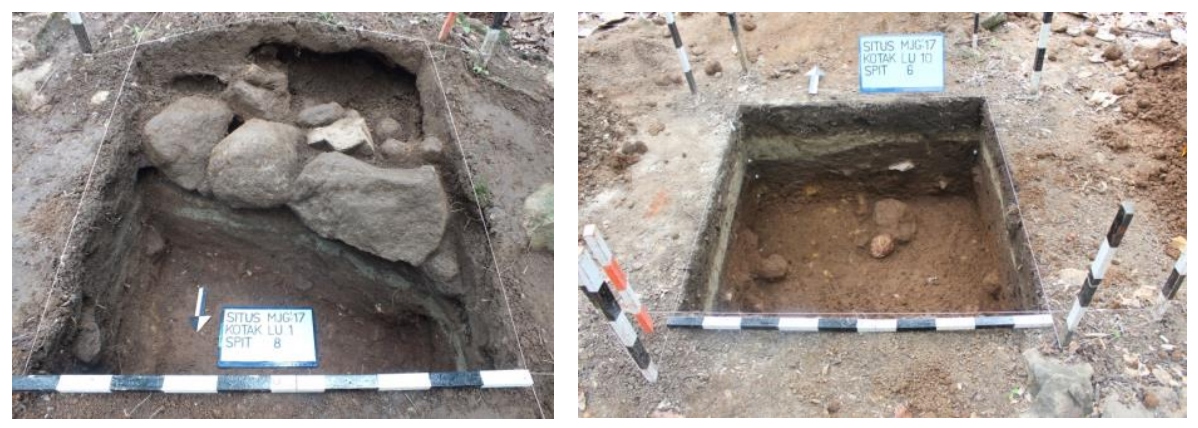

Gambar 6. Lapisan material vulkanik yang terlihat pada hasil ekskavasi (Sumber: Dokumen Balai Arkeologi Jawa Barat, 2017).

\section{SIMPULAN}

Erupsi Gunung Krakatau pada 1883 merupakan salah satu petaka besar yang pernah terjadi. Dampak dari letusan ini menimbulkan gelombang pasang yang menerjang pesisir Lampung dan Banten. Dalam tradisi lisan masyarakat kampungkampung di daerah pantai Teluk Lampung porak poranda. Masyarakat yang selamat kemudian memindahkan kampung ke tempat aman. Berdasarkan kajian volkanologi terhadap erupsi Gunung Krakatau, tsunami yang menyertai erupsi di Lampung mencapai ketinggian $15 \mathrm{~m}$. Kampung-kampung tua di pesisir barat Teluk Lampung berada pada ketinggian di atas $30 \mathrm{~m}$ sehingga kampung-kampung tua tidak terkena dampak langsung dari tsunami.

Ekskavasi pada salah satu situs kampung tua yaitu situs Pekon Tuha Maja telah menjumpai lapisan abu vulkanik dengan ketebalan variasi antara $5 \mathrm{~cm}$ hingga $10 \mathrm{~cm}$. Di bawah dan di atas lapisan abu vulkanik ditemukan artefak. Dengan kondisi demikian menunjukkan bahwa aktivitas penghunian situs Pekon Tuha Maja Saka berlangsung sebelum peristiwa erupsi dan berlangsung terus hingga sesudah peristiwa erupsi Gunung Krakatau. Letusan Gunung Krakatau 1883 memang merupakan bencana besar bagi pemukiman di kawasan pantai barat Teluk Lampung, namun perpindahan kampung-kampung tua ke lokasi baru bukan disebabkan bencana letusan Krakatau 1883 namun karena sebab lain.

\section{DAFTAR PUSTAKA}

Cas, R., \& Wright, J. (1988). Volcanic Succession: Modern and Ancient. London: Chapman \& Hall.

Christenson, B. W. (2000). Geochemistry of Fluids Associated with The 1995-1996

Eruption of Mt. Ruapehu, New Zealand: Signatures and Processes in the Magmatic-hydrothermal System. Journal of volcanology and geothermal research, 97(1-4), 1-30. 
Giachetti, T., Paris, R., Kelfoun, K., \& Ontowirjo, B. (2012). Tsunami Hazard Related to a Flank Collapse of Anak Krakatau Volcano, Sunda Strait, Indonesia.

Geological Society Special Publication, 361(1), 79-90. https://doi.org/10.1144/SP361.7

Hadikusuma, H. (1989). Masyarakat dan Adat Budaya Lampung. Bandung: Mandar Maju.

Haribuana, I. P. Y. (2013). Jejak Permukiman di Situs Tambora dan Sekitarnya: Perspektif Geomorfologi. Forum Arkeologi, 26(2), 125-134.

Imanududin, I. (2006). Bencana Krakatau 1883: Kajian Sejarah di Provinsi Lampung. Laporan Penelitian. Bandung.

Jokowinarno, D. (2009). Identifikasi Garis Pantai di Provinsi Lampung yang Rawan oleh Tsunami Sebagai Akibat Letusan Gunung Krakatau. Rekayasa, 13(2), 119130.

Kartodirdjo, S. (2015). Pemberontakan Petani Banten 1888. Depok: Komunitas Bambu.

Riyanto, S. (2015). Situs Liangan Ragam Data, Kronologi, dan Aspek Keruangan. Berkala Arkeologi, 35(1), 33-58. https://doi.org/10.30883/jba.v35i1.37

Saleh, M. (2014). Buku Syair Krakatau 1883 Risalah Lampung Karam. Jati Agung: Lamban Sastra.

Saptono, N. (2016). Perkembangan Kampung-kampung Tua di Sekitar Gunung Rajabasa Kabupaten Lampung Selatan. Bandung.

Saptono, N. (2018). Laporan Analisis Unsur Batuan Hasil Penelitian Situs Pekon Tuha Maja. Bandung.

Saptono, N., \& Widyastuti, E. (2015). Kampung-kampung Tua di Sekitar Gunung Rajabasa Kabupaten Lampung Selatan. Bandung.

Saptono, N., Widyastuti, E., \& Hidayat, D. (2017). Laporan Penelitian Arkeologi: Aktivitas Masyarakat di Situs Permukiman Pekon Saka Maja, Lampung Selatan. Bandung.

Suryadi. (2009). Syair Lampung Karam: Sebuah Dokumentasi Pribumi Tentang Dahsyatnya Letusan Krakatau 1883. Padang: Komunitas Penggiat Sastra Padang.

Tantri, E. (2014). Letusan Krakatau 1883: Pengaruhnya Terhadap Gerakan Sosial Banten 1888. Jurnal Masyarakat \& Budaya, 16(1), 191-214. https://doi.org/http://dx.doi.org/10.14203/jmb.v16i1.61

Wibisono, S. C. (2017). Bencana dan Peradaban Tambora 1815. Jakarta: Pusat Penelitian Arkeologi Nasional.

Zarman, R. (2013). Letusan Krakatau 1883 Dan Korban-korbannya di Desa Nelayan Karangantu Banten: Suatu Kesaksian Ong Leng Yauw. Jurnal Elektronik Wacana Etnik, 4(1), 67-99.

\section{HASIL DISKUSI}

Tidak ada pertanyaan 
